\title{
The effect of laparoscopy on mast cell degranulation and mesothelium thickness in rats
}

Hery Poerwosusanta ${ }^{1,2^{*}}$ (D) Gunadi ${ }^{3}$, Zairin Noor $^{4} \mathbb{D}$, Ika Kustiyah Oktaviyanti ${ }^{5} \mathbb{D}$, Karyono Mintaroem ${ }^{6} \mathbb{D}$, Bambang Pardjianto ${ }^{7}$, Moch Aris Widodo ${ }^{8}$ (I) and Edi Widjajanto ${ }^{9}$ (I)

\begin{abstract}
Background: Laparoscopy induces adhesion due to ischemia-reperfusion injury. However, the detail pathomechanism is poorly understood. This study aimed to investigate the impact of laparoscopy on mast cell and mesothelium morphological changes in the rat.

Methods: Forty-nine males of Sprague-Dawley Rattus norvegicus were divided into four groups: a) control and b) intervention groups P1, P2, and P3 that underwent 60 min laparoscopic using carbon dioxide $\left(\mathrm{CO}_{2}\right)$ insufflation at 8 , 10 , and $12 \mathrm{mmHg}$ groups, respectively. Serum hydrogen peroxide $\left(\mathrm{H}_{2} \mathrm{O}_{2}\right)$, catalase (CAT), superoxide dismutase (SOD), malondialdehyde (MDA), and oxidative stress index (OSI) levels were determined $24 \mathrm{~h}$ after laparoscopy. Histopathological analyses of mast cell infiltration and degranulation and mesothelium thickness in the liver, greater omentum, mesenterium, small intestine, and peritoneum were performed 7 days after the procedure.

Results: $\mathrm{H}_{2} \mathrm{O}_{2}, M D A$, and OSI levels were significantly increased in the intervention groups compared with the control $(p<0.05)$, while the SOD and CAT levels were decreased in the intervention groups compared with the control $(p<0.05)$. Mast cell infiltration and degranulation were higher in the intervention groups than in control $(p<$ 0.05), while the mesothelium thickness was significantly lower in the laparoscopic groups than in control $(p<0.05)$. Interestingly, the decrease in mesothelium thickness was strongly associated with the increase in mast cell infiltration and degranulation $(p<0.01)$.
\end{abstract}

Conclusions: Our study shows that laparoscopy in rats increases mast cell infiltration and degranulation, which also results in and correlates with a decrease in mesothelial thickness.

Keywords: Laparoscopic procedure, mast cell infiltration and degranulation, mesothelium thickness, oxidative stress, Rattus norvegicus

\footnotetext{
* Correspondence: herpoerwo@ulm.ac.id

'Doctoral Study Program, Faculty of Medicine, Universitas Brawijaya, Malang, Indonesia

²Department of Surgery, Ulin General Hospital, Faculty of Medicine, Universitas Lambung Mangkurat, Banjarmasin, Indonesia

Full list of author information is available at the end of the article
}

(c) The Author(s). 2020 Open Access This article is licensed under a Creative Commons Attribution 4.0 International License, which permits use, sharing, adaptation, distribution and reproduction in any medium or format, as long as you give appropriate credit to the original author(s) and the source, provide a link to the Creative Commons licence, and indicate if changes were made. The images or other third party material in this article are included in the article's Creative Commons licence, unless indicated otherwise in a credit line to the material. If material is not included in the article's Creative Commons licence and your intended use is not permitted by statutory regulation or exceeds the permitted use, you will need to obtain permission directly from the copyright holder. To view a copy of this licence, visit http://creativecommons.org/licenses/by/4.0/ The Creative Commons Public Domain Dedication waiver (http://creativecommons.org/publicdomain/zero/1.0/) applies to the data made available in this article, unless otherwise stated in a credit line to the data. 


\section{Background}

At present, laparoscopy is the preferred and standard surgical technique. This procedure requires insufflation of carbon dioxide $\left(\mathrm{CO}_{2}\right)$ for better visualization but affects the mesothelium membrane [1] and changes the local morphology to a certain degree [2]. Although laparoscopy decreases the risk of mesothelial damage up to $25 \%$ compared to laparotomy [3], detachment of mesothelial cells during laparoscopic surgery still occurs and causes adhesion formation [4]. Information about pathomechanism and how to prevent mesothelial cell detachment is rarely found.

Mast cells are specific cells that mature in peripheral tissues, including the peritoneum [5], and can produce proteases (e.g., tryptase, chymase, and carboxypeptidase A3), which are retained in cytosolic granules during the resting phase. Mast cells can be activated through several pathways and degranulation results in the release of proteases in a protective response to injuries. Effect of tryptase promotes extracellular matrix deposition (ECM) by activating proteinase-activated receptors (PAR)-2 in ECM fibroblasts. Chymase affects tight junction proteins and causes cell release from the basement membrane [6]. Mast cell degranulation thought to play a role in mesothelial cell damage. Damage to mesothelial cells through degranulation of mast cells can cause complications, that is, intra-abdominal adhesion.

Laparoscopy results in ischemia-reperfusion injury, causing a transient hypoxia of abdominal organs [2]. These effects will decrease after desufflation [2]. During ischemia, cells in the peritoneum develop reactive oxygen species (ROS), which can damage tissues and cause adhesions [7]. Ten percent of the immune cells commonly found in the mesothelium layer are mast cells [8]. Pneumoperitoneum induces free radicals production by mesothelium and also mast cells [9]. Our study investigated the impact of laparoscopy on mast cells and mesothelium morphological changes in rats. In this study, we used rats because they have similar physiological and immunological aspects with human $[10,11]$.

\section{Methods}

\section{Animals}

According to the Federer formula [12], 49 males (200$250 \mathrm{~g}$ and 20-25 weeks) Sprague-Dawley Rattus norvegicus from the Abadi Jaya farm in Yogyakarta, Indonesia, were used for this study. This study followed the main principles of experimental animals, i.e., 3R (replacement, reduction, and refinement) and $5 \mathrm{~F}$ (freedom of hunger and thirst, freedom from discomfort, freedom of pain, injury, or disease, freedom to fear and distress, and freedom to express natural behaviour). Male rats were preferred because they are stronger, and have higher blood volume than the females, and to avoid the estrus hormonal phase in the female rats [13] The rats were treated according to standard conditions for single housing and breeding. Heart rate, body temperature, and activity were checked for 7 days of acclimation. The room was maintained in a controlled $12 \mathrm{~h}$ light/dark cycle at $20 \pm 2^{\circ} \mathrm{C}$ temperature and relative humidity of $45-70 \%$ [14]. The rats were randomized into one control group, and three intervention groups: the control group $(n=7)$ did not undergo pneumoperitoneum, while the intervention groups P1 $(\mathrm{n}=14)$, P2 $(\mathrm{n}=14)$, and P3 $(\mathrm{n}=14)$ were given 8,10 , and $12 \mathrm{mmHg} \mathrm{CO}_{2}$ pneumoperitoneum, respectively.

This research conformed to the institutional protocol for euthanasia (http://risetcenterfk.ulm.ac.id/euthanasia/) and has been approved by the Animal Experimentation Ethical Committee, Research Center, Faculty of Medicine, Lambung Mangkurat University, Banjarmasin, Indonesia (\#116-118/KEPK-FK.UNLAM/EC/X/2015).

\section{Laparoscopic procedure and sample collection}

Laparoscopic surgery was performed under sterile conditions. Abdominal hair was shaved and disinfected with betadine (10\% povidone-iodine solution; PT Mahakam Beta Farma, Indonesia No. Reg. DTL 1013705941A1). The rats were anaesthetized with an intramuscular injection of ketamine $\mathrm{HCl}$ (KTM-10; PT Guardian Pharmatama, No. Reg. DKL0408013443B1) at a dose of $10 \mathrm{mg} /$ $\mathrm{kg}$ BW. Standard $\mathrm{CO}_{2}$ and $\mathrm{CO}_{2}$ automatic insufflators (Gimmi, Gimmi ${ }^{\circ} \mathrm{GmbH}$, Germany, 2000) were used for pneumoperitoneum. $\mathrm{CO}_{2}$ pneumoperitoneum was divided into three phases for all groups as follows: a) phase 1: stabilization. After the cannula was performed, the rats were stabilized; b) phase 2: pneumoperitoneum (insufflation). $\mathrm{CO}_{2}$ insufflators were connected via an 18gauge needle by peritoneal penetration. The pressure was set at 8,10, or $12 \mathrm{mmHg}$; and c) phase 3: desufflation. Desufflation was performed twice during the laparoscopy: the first desufflation was in the middle of the laparoscopy due to the change of instruments, while the final one was before the end of the surgery (Fig. 1).

\section{Stress oxidative analysis}

Twenty-four hours after laparoscopy, the rats were sacrificed in ketamine injections and followed by neck dislocations. Heart blood samples were collected using vacutainers containing ethylenediaminetetraacetic acid. Samples were centrifuged for $10 \mathrm{~min}$ at $3000 \mathrm{rpm}$, and the supernatants were harvested and stored at $-20^{\circ} \mathrm{C}$ until further analysis. The supernatant used for the analysis $\mathrm{H}_{2} \mathrm{O}_{2}, \mathrm{CAT}$, SOD, and MDA. Analyses were performed in the chemical/biochemistry laboratory of Universitas Lambung Mangkurat. 


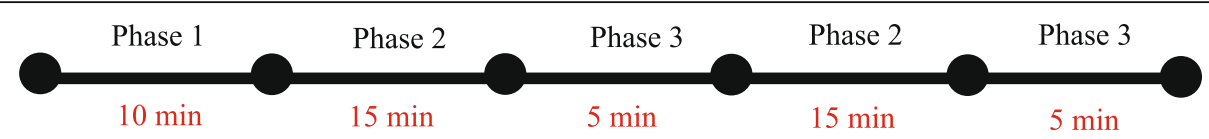

Fig. 1 Pneumoperitoneum phase. Desufflation was performed twice during the laparoscopy: the first desufflation in the middle of the laparoscopy due to the change of instruments and the final one was before the end of the surgery.

\section{Hydrogen peroxide $\left(\mathrm{H}_{2} \mathrm{O}_{2}\right)$}

The level of $\mathrm{H}_{2} \mathrm{O}_{2}$ was measured using the colourimetric modification method [15]. Briefly, 0.01 M phosphate buffer ( $\mathrm{pH} 7.0$ ) was prepared using $5 \% \mathrm{~K}_{2} \mathrm{Cr}_{2} \mathrm{O}_{7}, 150 \mathrm{~mL}$ glacial acetate, and $0.2 \mathrm{M} \mathrm{H}_{2} \mathrm{O}_{2}$. Adjust to a standard curve with a concentration of $\mathrm{H}_{2} \mathrm{O}_{2}$ of 20-160 $\mu \mathrm{mol}$. Serum was added to the phosphate buffer (1:5); $1 \mathrm{~mL}$ of this mixture was added to $2 \mathrm{~mL}$ glacial acetate. The sample was boiled to remove the blue precipitate and measured by colorimetry at $\lambda=570 \mathrm{~nm}$. The results are expressed as $\mu \mathrm{M}$.

\section{Catalase (CAT)}

The Aebi method was used for measuring CAT activity [16]. Guaiac solution was prepared with phosphatebuffered saline $(\mathrm{pH} \mathrm{7})$, and the serum sample and 10 $\mathrm{mM} \mathrm{H} \mathrm{H}_{2} \mathrm{O}_{2}$ were added ( $1 \mathrm{~mL}$ each). The absorbance was measured at $470 \mathrm{~nm}$ (A1) and $570 \mathrm{~nm}$ (A2).

\section{Superoxide dismutase (SOD)}

The Misra and Fridovich method was used to measure SOD activity [17]. Carbonate buffer (100 mM, pH 10.2 using $0.528 \mathrm{~g} \mathrm{Na}_{2} \mathrm{CO}_{3}$ in $100 \mathrm{~mL}$ sterile water) was prepared. A $500 \mu \mathrm{L}$ sample was added to $800 \mu \mathrm{l}$ carbonate buffer and $100 \mu \mathrm{L} 3 \mathrm{mM}$ epinephrine. One milliliter of carbonate buffer was used as the blank solution. The standard solution was $900 \mu \mathrm{L}$ carbonate buffer $+100 \mu \mathrm{L}$ $3 \mathrm{mM}$ epinephrine. The absorbance of the sample solution was measured at $480 \mathrm{~nm}$ (A0) and repeated after 15 $\mathrm{s}$ for $\mathrm{A} 1$ then compared to the standard solution. One unit of SOD activity was defined as the amount of enzyme that inhibits the rate of epinephrine oxidation by $50 \%$.

\section{Malondialdehyde (MDA)}

Buege and Aust's method was used for determining the MDA level by measuring thiobarbituric acid reactive substances [18]. A $0.5 \mathrm{ml}$ sample was prepared, and $1.25 \mathrm{ml} 40 \%$ TCA, $200 \mu \mathrm{L} 1 \mathrm{~N} \mathrm{HCl}, 0.5 \mathrm{ml}$ sterile water, and $100 \mu \mathrm{l}$ NaThio were added. The mixtures were heated for $25 \mathrm{~min}$ at $100^{\circ} \mathrm{C}$, centrifuged for $5 \mathrm{~min}$ at $3000 \mathrm{rpm}$, and the supernatants were harvested. The sample was then diluted with sterile water up to $3 \mathrm{~mL}$. Solutions were measured spectrophotometrically at $\lambda=$ 500-600 nm.

\section{Oxidative stress index (OSI)}

OSI is defined as the ratio between MDA and the total activity of SOD and CAT. Therefore, OSI can be calculated using the following equation [19]:

$$
O S I\left(\frac{\mu M}{\text { unit }}\right)=\frac{M D A}{S O D+C A T}
$$

\section{Histological analysis of mast cell infiltration and degranulation}

Seven days after laparoscopy, the rats were sacrificed in ketamine injections and followed by neck dislocations. The greater omentum, mesenterium, and peritoneum were collected for analysis. The samples were washed in saline, placed in object-glass, and dried at $70^{\circ} \mathrm{C}$ for 3 min. Samples were stained with toluidine blue for $5 \mathrm{~min}$. Mast cell evaluation was performed using an Olympus (Japan) CX31 microscope and an Olympus U-TV1X-2 lens (100× magnification). Histological images were captured with GraBee version 2.0.0. Mast cell degranulation was measured by dividing the number of degranulated mast cells by the total number of mast cells and expressed as a percentage. Evaluations were performed independently by three pathologists who were blinded to the in 4" (100× magnification).

\section{Histological analysis of mesothelium thickness}

Seven days after laparoscopic, the rats were sacrificed in ketamine injections and followed by neck dislocations. Samples of the liver, small intestine $1 \mathrm{~cm}$ from the proximal colon, greater omentum, and peritoneum were collected for analysis. Tissues were fixed in 10\% formaldehyde solution and prepared for paraffin blocks. Samples were dehydrated and made using a microtome and stained with hematoxylin and eosin in a thickness of 5 $\mathrm{mm}$. Images were captured with GraBee version 2.0.0, and ImageJ was used to measure the distance from the basal membrane to the edge. Evaluations were performed independently by pathologists who were blinded to the study in $4 "$ (100× magnification).

\section{Statistical analysis}

Data were presented as numbers, percentages, mean \pm standard deviation, and median (minimum-maximum). First, we performed using Kolmogorov-Smirnov, and 
Shapiro-Wilk normality tests and Levene's homogeneity test. Data transformation methods (power $>1$, inverse, $\log 10$, and square root) were used for not-normal and not-homogeneous distribution data, followed by oneway analysis of variance, Kruskal-Wallis, or Welch tests for comparison. Multiple range tests used post hoc Tukey's honestly significant difference test, post hoc Games-Howell, Mann-Whitney, or independent sample tests. A confidence interval of $95 \%(\alpha=0.05)$ was used for comparison significance. Spearman correlation with the significance of $\alpha=0.01$ was used to analyze relationships between variables. The analysis was performed using SPSS version 17.0 and Microsoft Excel 2010.

\section{Results}

$\mathrm{H}_{2} \mathrm{O}_{2}$ level increased after laparoscopy

The $\mathrm{H}_{2} \mathrm{O}_{2}$ level was higher in the intervention groups compared with the control group (3.50 [range, 3.393.61] vs. 6.04 [range, 5.24-6.49] vs. 8.41 [range, 7.059.48] vs. 11.37 [range, 9.54-12.93] $\mu \mathrm{M}$ for control, P1, P2, and P3 groups, respectively; $p<0.05$ ) (Fig. 2a).

\section{MDA level increased after laparoscopy}

Lipid membrane peroxidation was analyzed by determining MDA levels $24 \mathrm{~h}$ after laparoscopy. Serum MDA was higher in the intervention groups than in the control group (3.92 [range, 3.89-3.95] vs. 4.32 [range, 4.20-4.40] vs. 4.73 [range, 4.69-4.84] vs. 8.24 [range, 7.87-9.24] $\mu \mathrm{M}$ for control, P1, P2, and P3 groups, respectively; $p<0.05$ ) (Fig. 2b).

\section{Antioxidant level of CAT and SOD level decreased after laparoscopy}

The CAT level was significantly higher in the control group than in the intervention groups (28.00 [range, 27.98-28.55] vs. 23.09 [range, 19.49-26.11] vs. 11.58 [range, 10.18-15.72] vs. 8.24 [range, 4.26-8.72] $\mu \mathrm{M}$, for control, P1, P2, and P3 groups, respectively; $p<0.05$ ) (Fig. 2c).

The SOD level was also significantly higher in the control than in the intervention groups $(0.153$ [range, $0.148-$ 0.154 ] vs. 0.142 [range, 0.102-0.161] vs. 0.116 [range, 0.093-0.166] vs. 0.01 [range, 0.003-0.109] $\mu \mathrm{M}$ for control, P1, P2, and P3 groups, respectively; $p<0.05$ ) (Fig. 2d).

\section{OSI increased after laparoscopy}

OSI is defined as the ratio between MDA and the total activity of SOD and CAT. Rats that received pneumoperitoneum showed a higher index than in the control group and was directly proportional to the pressure level $(0.14 \pm 0.00$ vs. $0.19 \pm 0.02$ vs. $0.40 \pm 0.05$ vs. $1.14 \pm 0.35$ for control, P1, P2, and P3 groups, respectively, $p<0.05$ ) (Fig. 2e).

\section{Mastocytosis (mast cell infiltration)}

Mastocytosis was significantly higher in the intervention groups than in the control group $(216.43 \pm 43.58$ vs.

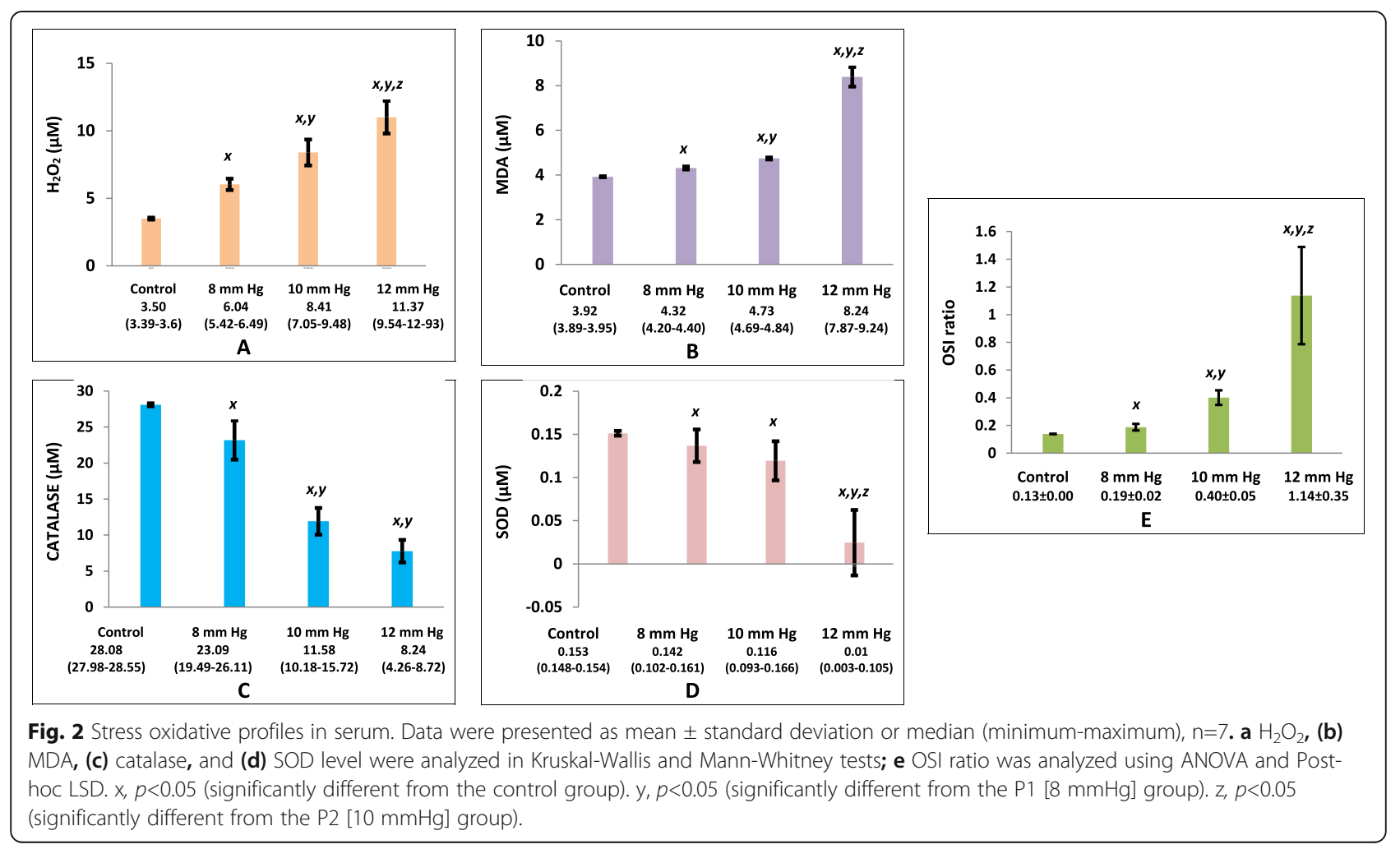



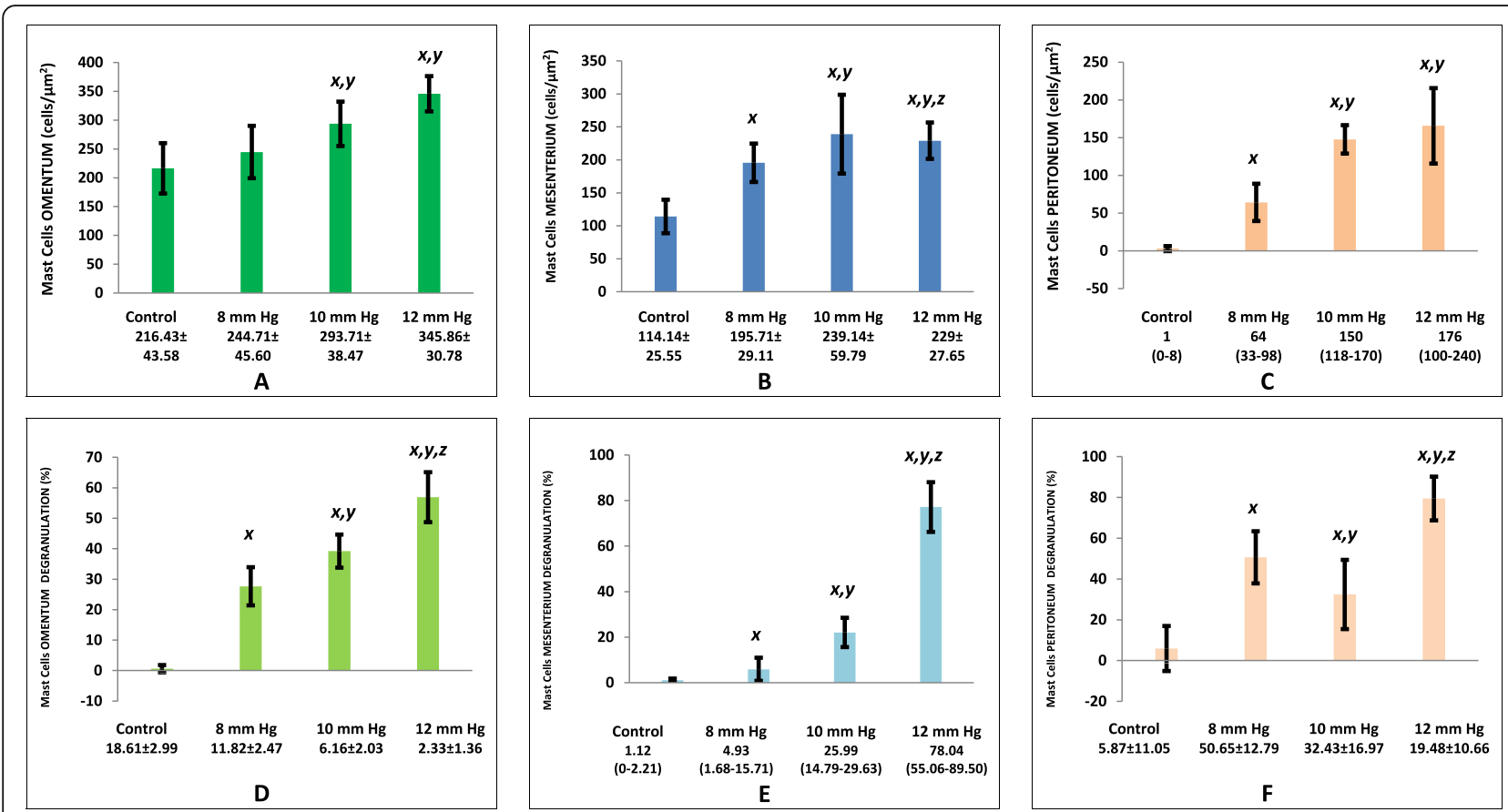

Fig. 3 Mast cell infiltration (mastocytosis) and degranulation. Data were presented in mean \pm standard deviation or median (minimummaximum), $n=7$. Mast cell infiltration in omentum (a) and mesenterium (b) were analyzed in ANOVA and Post-hoc LSD. Mast cell infiltration in peritoneum (c), mast cell degranulation in omentum (d), and mast cell degranulation in mesenterium (e) were analyzed in Kruskal-Wallis and Mann-Whitney. Mast cell degranulation in peritoneum (f) was analyzed in ANOVA and Post-hoc LSD. $x, p<0.05$ (significantly different from the control group). $y, p<0.05$ (significantly different from the P1 [8 mmHg] group). $z, p<0.05$ (significantly different from the P2 [10 mmHg] group).

$244.71 \pm 45.60$ vs. $293 \pm 38.47$ vs. $345.86 \pm 30.78 ; 114.14$ \pm 25.55 vs. $195.71 \pm 29.11$ vs. $239.14 \pm 59.79$ vs. $229 \pm$ 27.65; and 1 [range, 0-8] vs. 64 [range, 33-98] vs. 150 [range, 118-170] vs. 176 [range, 100-240] in the greater omentum, mesenterium, and peritoneum, respectively for control, P1, P2, and P3 groups, respectively, $p<0.05$ ) (Fig. 3a-c and 4).

\section{Mast cell degranulation}

There was significantly higher mast cell degranulation in the intervention groups than in the control group (0.01 [range, 0-3.21] vs. 26.53 [range, 19.3-35.81] vs. 40.99 [range, 30.94-46.63] vs. 57.23 [range, 42.93-65.23]; 1.12 [range, 0-2.21] vs. 4.93 [range, 1.68-15.71] vs. 25.99 [range, 14.79-29.63] vs. 78.04 [range, 55.06-89.50]; and 0.01 [range, 0-28.6] vs. 53.1 [range, 27.27-68.00] vs. 24.03 [range, 18.4-66.10] vs. 80.85 [range, 65.00-93.50] in the greater omentum, mesenterium, and peritoneum, respectively, for control, P1, P2, and P3 groups, respectively, $p<0.05$ ) (Fig. 3d-f and 4).

\section{Mesothelium thickness}

The mesothelium was significantly thicker in the control group than in the intervention groups $(18.61 \pm 2.99 v s$. $11.82 \pm 2.47$ vs. $6.16 \pm 2.03$ vs. $2.33 \pm 1.35 ; 10.31$ [range, 7.35-13.1] vs. 3.41 [range, 0-7.92] vs. 2.88 [range, 1.13-
5.28] vs. 1.16 [range, 0-1.75]; 62.4 [range, 46.35-119.33] vs. 25.47 [range, 12.18-29.41] vs. 8.41 [range, 0-14.32] vs. 0.01 [range, 0-4.32]; and 11.40 [range, 9.50-13.15] vs. 4.30 [range, 2.40-6.47] vs. 1.01 [range, 0-3.01] vs. 0.39 [range, $0-0.65$ ] $\mu \mathrm{M}$ in the peritoneum (Fig. 5a), greater omentum (Fig. 5b), liver (Fig. 5c), and small intestine (Fig. 5d), respectively, for control, P1, P2, and P3 groups, respectively, $p<0.05$ ) (Fig. 6).

\section{Associations between mastocytosis and mast cell degranulation with mesothelium thickness}

There was a significant correlation between mastocytosis and mast cell degranulation and change in mesothelium thickness in the peritoneum, greater omentum, small intestine, and liver mesothelium $(p<0.01)$.

\section{Discussion}

Laparoscopy has fewer potential complications than laparotomy [20], such as adhesions, intestinal obstruction, infertility, and chronic pelvic pain $[2,9] . \mathrm{CO}_{2}$ insufflation for good visualization during surgery causes hypoxic and splenic ischemia and triggers peritoneal adhesion $[9,21]$. The duration of insufflation is proportional to the risk of complications. Insufflation causes mesothelium ischemia and increases hypoxanthine as a product of anaerobic cell metabolism. Cell ischemia 


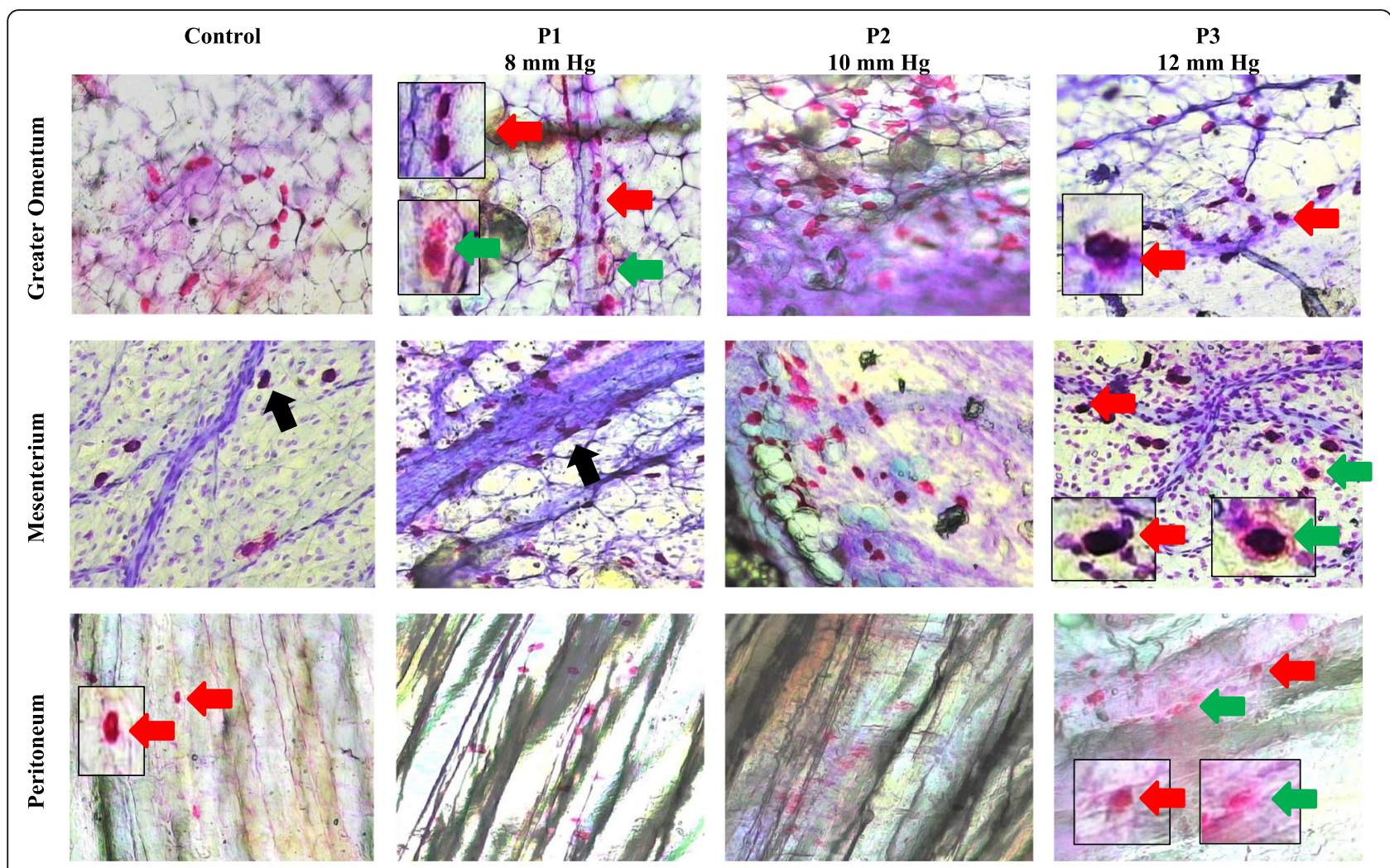

Fig. 4 Histological findings of mast cell infiltration (mastocytosis) and degranulation (toluidine blue, $40 \mathrm{X}$ magnifications). Due to increased pressure during laparosocpy, there was an increase in the number and degranulation of mast cells in the omentum, mesenterium, and peritoneum. Red arrows indicate non-degranulated mast cells, and green arrows indicate degranulated mast cells. The mast cells were commonly identified in perivascular (black arrow).
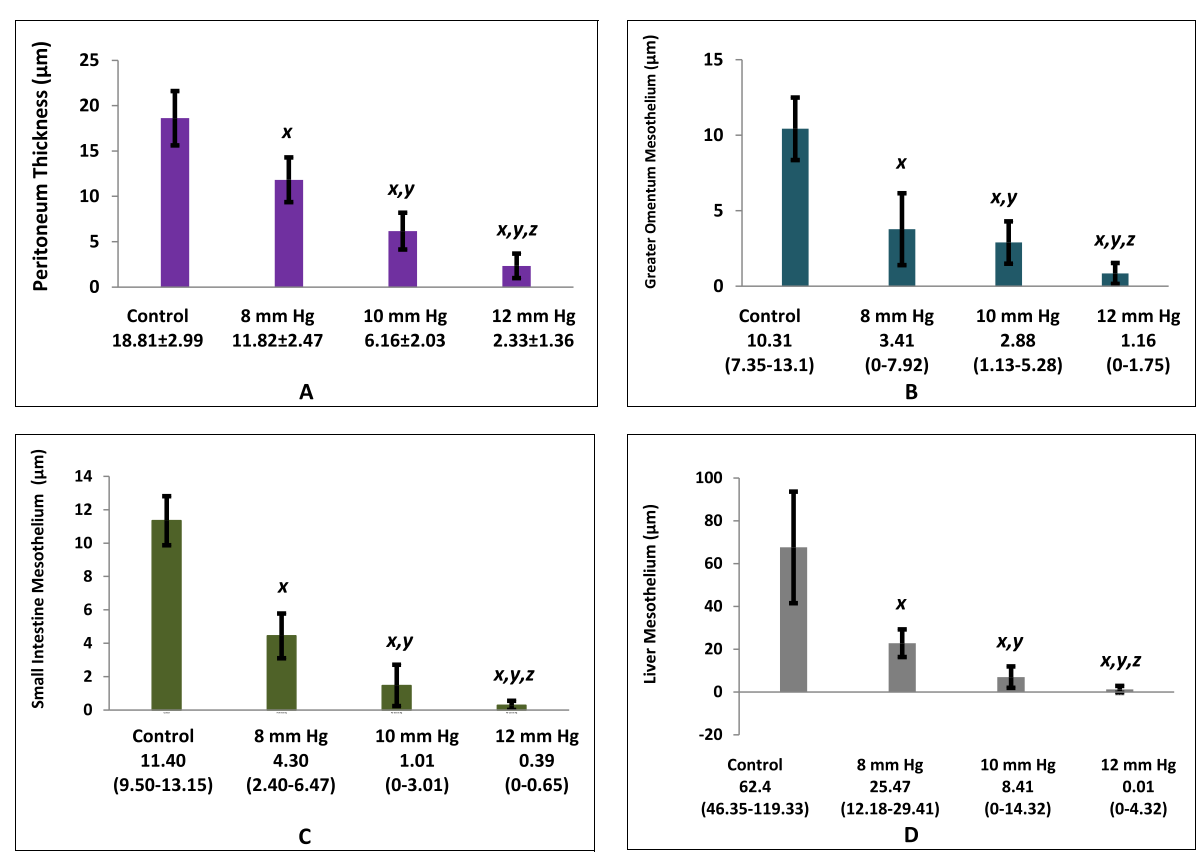

Fig. 5 Mesothelium thickness. Mesothelium thickness in peritoneum (a) was analyzed in ANOVA and Post-hoc LSD. Mesothelium thickness in greater omentum (b), small intestine (c), and liver (d) were analyzed in Kruskal-Wallis and Mann-Whitney. $x, p<0.05$ (significantly different from the control group). $y, p<0.05$ (significantly different from the P1 [8 mmHg] group). $z, p<0.05$ (significantly different from the P2 [10 $\mathrm{mmHg}]$ group). 


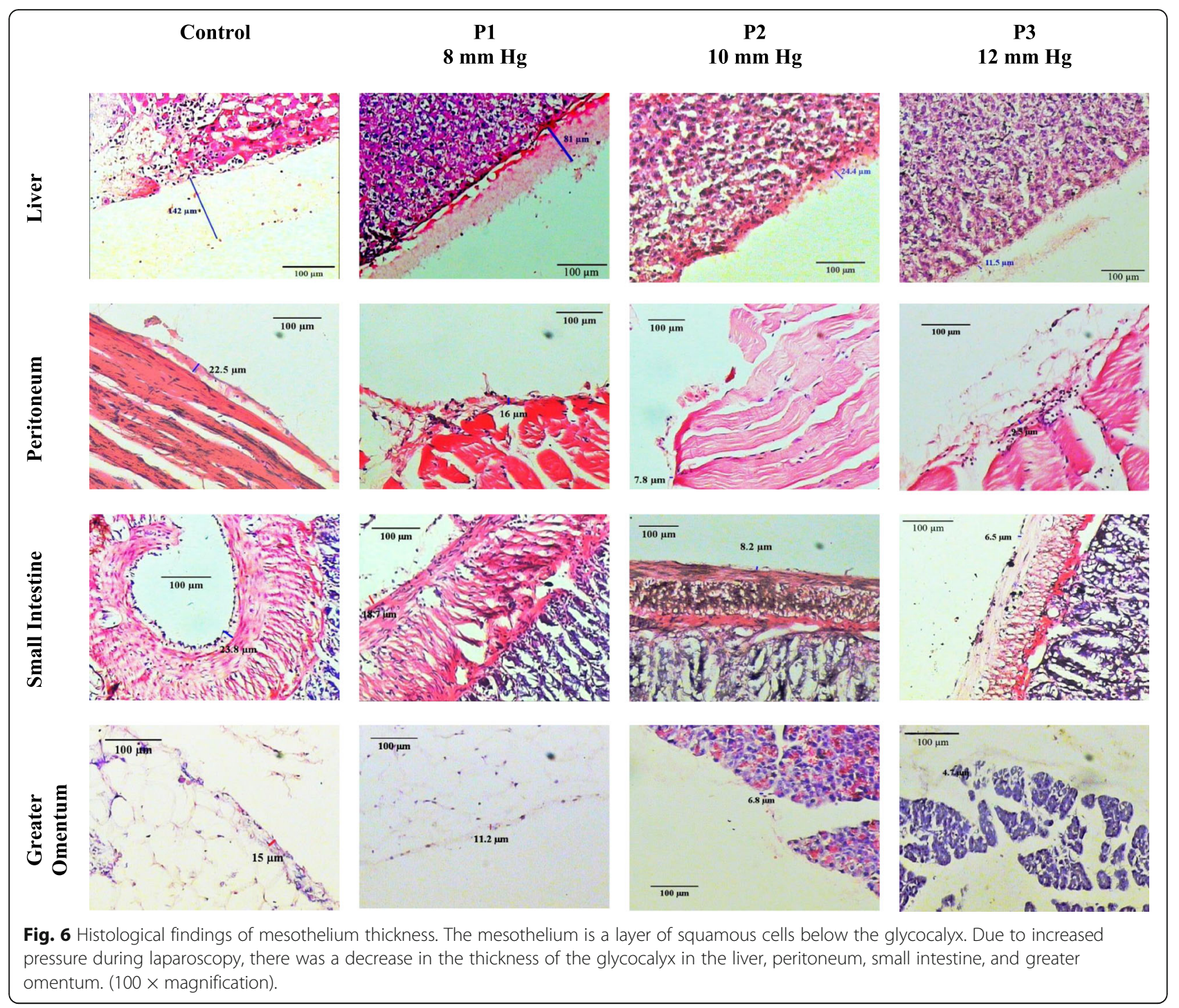

produces proteases and activates xanthine oxidase. Both will react with oxygen during desufflation, increasing ROS production [22, 23]. ROS damage the tissue and cause adhesions. Ten percent of the immune cells commonly found in the mesothelium layer are mast cells. Mast cells are part of the innate immune system, increase and attract other immune cells after laparoscopy [23]. Our study showed that laparoscopy induces oxidative stress, increases infiltration and degranulation of mast cells, which causes morphological damage to the mesothelium membrane.

ROS consists of free radicals and not free radicals. Superoxide anions, hydroxyl radicals, and nitric oxide are unstable and are converted to free radicals by SOD to $\mathrm{H}_{2} \mathrm{O}_{2}$. These radicals cause extensive intracellular damage to DNA, proteins, or lipid membranes, induce inflammatory reactions [24], and adhesion formation after surgery [25]. Serum $\mathrm{H}_{2} \mathrm{O}_{2}$ is a reliable parameter for measuring oxidant levels and reflects ischemic reperfusion injury after laparoscopy. Our study found that $\mathrm{H}_{2} \mathrm{O}_{2}$ concentration significantly increased proportionally to insufflation pressure. Increased ROS production by peritoneal macrophages has also been reported as an increase in superoxide anion [26].

Increasing ROS due to the decrease of enzyme activity that converting the oxidants to $\mathrm{H}_{2} \mathrm{O}_{2}$, subsequently to water and oxygen. SOD is the responsible enzyme for the $\mathrm{H}_{2} \mathrm{O}_{2}$ formation. CAT and glutathione peroxidase convert $\mathrm{H}_{2} \mathrm{O}_{2}$ into water and oxygen. Our study found that SOD and CAT levels decreased significantly in the intervention groups. Oksuz et al. showed that SOD levels decrease after laparoscopy and antioxidant injections increase SOD levels [27]

Oxidative stress can be assessed through damage to the lipid membrane, DNA, and protein degradation. Lipid membrane peroxidation was analyzed through 
MDA levels 24 hours after laparoscopy. Our study found that MDA levels increase significantly in line with pressure. Langendonckt et al. found that human plasma MDA levels increase 5 minutes after laparoscopy. There was no significant increase in MDA 24 hours postoperatively [25]. MDA is the final product of oxidative stress, and our data support that desufflation and reperfusion contribute to the formation of ROS.

OSI is the ratio between cell damage (MDA) and the availability of endogenous antioxidants (the amount of SOD and CAT). Our study found that OSI increased significantly according to increased insufflation pressure and compatible with the previous report [21].

Mastocytosis is an abnormal mast cell proliferation [28], caused by mutations of CD117 [29]. Mastocytosis can be analyzed by histological examination [30]. Mast cells have a unique characteristic, released from bone marrow as immature progenitor mast cells into circulation while expressing various surface molecules and integrins precisely according to their home tissues [31]. In peripheral tissues, mast cells will mature, producing mediators according to their microenvironment. Once activated, mast cells can respond accurately to cell damage [32, 33].

Our study revealed that a significant increase in mast cell infiltration 7 days after laparoscopy, and the increase was proportional to the level of pressure. Mastocytosis can increase in peripheral tissue or additional recruitment from bone marrow [34]. Sonoda et al. found that skin generates mature mast cells [35]. Migration of mast cell progenitors to the peritoneal membrane depends on the integrins $\alpha \mathrm{M} \beta 2$ and $\alpha \operatorname{IIb} \beta 3$ [36, 37]. Expression of these integrins is highly specific; it differs from VCAM-1 and the integrins $\alpha 4 \beta 1$ and $\alpha 4 \beta 4$, which are needed for intestinal migration [38]. Those findings are consistent with the study of Jamur, who demonstrated that mast cell precursors increase in the bone marrow, producing mast cell progenitors that migrate and infiltrate the peritoneal membrane after being depleted with saline [39]. In allergic reactions, tissue mast cell progenitors increase in number following sensitization [40]. Following peritoneal insufflation, Volz et al. observed local acidosis in the mesothelium layer, together with endotoxin, nonspecific noxae become a chemotactic factor in attracting immune cell infiltration to the site, as an initial reaction in peritoneal healing [41].

In the resting phase, mast cells develop granules that consist of active metabolites such as biogenic amines, cytokines, and peptides, as well as proteases (tryptase and chymase), which are released upon activation (degranulation). Connective tissue mast cells are known to have 10-fold lower expression of FcERI than mucosal mast cells for activation; mast cells can also be activated by non-immune mediators such as complement, substance
48/80, and substance P [42]. Our study found that there was a relationship between mast cell degranulation and mesothelial thickness. The mast cell degranulation increased significantly with increased pressure. These data are supported by Steiner et al. Mast cells can also be activated by substance $48 / 80$ and degranulation. Soluble granules become chemokines that attract other immune cells and induce inflammation [43]. FcERI can mediate degranulation by producing intracellular ROS through Lyn and Syk activation, which increases the cytoplasmic concentration of calcium [44].

Insufflation creates shear stress and increases intraabdominal pressure. Both are mechanical pathways to stimulate degranulation of local mast cells $[45,46]$. Stretching and changes in pressure activate TPRV4 channels of mechanosensitive calcium ions in mast cells, cause calcium to enter the cytoplasm. Calcium has a vital role in releasing stored proteases because increased intracellular calcium stimulates and activates mast cells [47].

Our study also presented that high pressure caused a significant decrease in mesothelium thickness, which was measured in the parietal peritoneum, small intestine, liver, and greater omentum. The damage might be induced by ischemia-reperfusion injury during insufflation and desufflation, which is known to increase ROS and nitrogen species harmful to parenchyma and vascular $[48,49]$. The glycocalyx is one structure susceptible to oxidative damage [50]. The results are supported by the study of Debray-Gracia et al., in which oxidative stress was induced in the diabetic peritoneum by peritoneal dialysis [51]. It was found that protein carbonylation, an oxidative damage marker, increased, tight junctions were altered, and the thickness of the sub-mesothelium and connective tissue decreased. Ten minutes after oxidant exposure, mesothelial cells begin to die through necrosis and apoptosis, resulting in a reduction of the cell population, and 30 days later, the mesothelium layer began to repopulate together with the development of fibrotic tissue [52], an early stage of adhesion formation. Oxidants, such as extracellular $\mathrm{H}_{2} \mathrm{O}_{2}$, can induce intracellular ROS by activating $\mathrm{PKC}$ in a human peritoneum mesothelial cell (in vitro study) [53].

Mesothelium thinning was significantly correlated with mastocytosis and mast cell degranulation. Mast cells exocytosis, released protease tryptase and chymase, directly or indirectly decreased ECM, fibronectin, and collagen of the mesothelium [54]. ZO-1 tight junction proteins altered and changed cell permeability [55-58]. Overall, mast cell degranulation triggered mesothelium thinning, caused oxidant-induced glycocalyx damage, and led to the development of fibrotic and adhesion formation.

Our study proved that mast cells caused mesothelium damage. Degranulation of mast cells after laparoscopic 
induced mesothelial cell damage and led to complications, i.e., intra-abdominal adhesion.

There was a limitation in our study that used systemic blood samples oxidative parameters and did not determine the direct correlation between oxidative stress and mast cells in the abdominal cavity. Three insufflation pressures significantly caused the expected damage. Future study, in particular, about pressures lower than 8 $\mathrm{mmHg}$, additional variables to explain the effects of oxidative stress (i.e., using peritoneal fluid samples) and their implications for mast cells and products (i.e., histamine, tryptase, chymase), as well as treatment to avoid complications, needs to be done. A deeper understanding of mast cells in the mesothelium layer can be expected to improve laparoscopy in the future.

\section{Conclusions}

Our study shows that laparoscopy in rats causes stress oxidative, results in a decrease in mesothelial thickness that is correlated with mast cell infiltration and degranulation. Degranulation of mast cells results in mesothelial cell damage and makes the loss of glycocalyx protective function and might cause complications, such as an intra-abdominal adhesion.

\section{Abbreviations}

$\mathrm{CO}_{2}$ : Carbon dioxide; CAT: Catalase; ECM: Extracellular matrix; $\mathrm{H}_{2} \mathrm{O}_{2}$ : Hydrogen peroxide; MDA: Malondialdehyde; OSI: Oxidative stress index; PAR-2: Proteinase-activated receptor-2; ROS: Reactive oxygen species; SOD: Superoxide dismutase.

\section{Acknowledgements}

We thank E Suhartono for assistance with laboratory analysis and KN Benita for writing support.

\section{Authors' contributions}

$H P, G, Z N, I K O, K M, B P, M A W$ and EW conceived the study. HP drafted the manuscript, G, ZN, IKO, KM, BP, MAW, and EW critically revised the manuscript for important intellectual content. All authors have read and approved the final manuscript and agreed to be accountable for all aspects of the work in ensuring that questions related to the accuracy or integrity of any part of the work appropriately investigated and resolved.

\section{Funding}

No funding was received for this study.

\section{Availability of data and materials}

The datasets used and/or analyzed during the current study are available from the corresponding author on reasonable request.

\section{Ethics approval and consent to participate}

This research conformed to the institutional protocol for euthanasia (http:/ risetcenterfk.ulm.ac.id/euthanasia/) and has been approved by the Animal Experimentation Ethical Committee, Research Center, Faculty of Medicine, Lambung Mangkurat University, Banjarmasin, Indonesia (\#116-118/KEPKFK.UNLAM/EC/X/2015). The experiments were conducted in the Chemical/ Biochemical Laboratory, Faculty of Medicine, Lambung Mangkurat University, Banjarmasin, Indonesia.

\section{Consent for publication}

Not applicable.

\section{Competing interests}

The authors declare that they have no conflict of interest.

\section{Author details}

'Doctoral Study Program, Faculty of Medicine, Universitas Brawijaya, Malang, Indonesia. ${ }^{2}$ Department of Surgery, Ulin General Hospital, Faculty of Medicine, Universitas Lambung Mangkurat, Banjarmasin, Indonesia. ${ }^{3}$ Pediatric Surgery Division, Department of Surgery, Faculty of Medicine, Public Health and Nursing, Universitas Gajah Mada /Dr. Sardjito Hospital, Yogyakarta, Indonesia. ${ }^{4}$ Department of Surgery, Ulin General Hospital, Faculty of Medicine, Universitas Lambung Mangkurat, Banjarmasin, Indonesia. ${ }^{5}$ Department of Anatomical Pathology, Faculty of Medicine, Universitas Lambung Mangkurat, Banjarmasin, Indonesia. ${ }^{6}$ Department of Biomedical Science, Faculty of Medicine, Universitas Brawijaya, Malang, Indonesia. ${ }^{7}$ Department of Biomedical Science, Faculty of Medicine, Universitas Brawijaya, Malang, Indonesia. ${ }^{8}$ Department of Biomedical Science, Faculty of Medicine, Universitas Brawijaya, Malang, Indonesia. ${ }^{9}$ Department of Biomedical Science, Faculty of Medicine, Universitas Brawijaya, Malang, Indonesia.

Received: 1 March 2019 Accepted: 13 May 2020

Published online: 24 May 2020

\section{References}

1. Shapiro L, Holste $\mathrm{J}$, , Muench T. Rapid reperitonealization and wound healing in a preclinical model of abdominal trauma repair with a composite mesh. Int J Surg. 2015;22:86-91.

2. Papparella A, Nino F, Coppola S, Noviello C, Paciello O, Papparella S. Peritoneal morphological changes due to pneumoperitoneum: The effect of intra-abdominal pressure. Eur J Pediatr Surg. 2014;24(4):322-7.

3. Okabayashi K, Ashrafian H, Zacharakis E, Hasegawa H, Kitagawa Y, Athanasiou T, et al. Adhesions after abdominal surgery: A systematic review of the incidence, distribution and severity. Surg Today. 2014;44(3):405-20.

4. Stommel MW, ten Broek RP, Strik C, Slooter GD, Verhoef C, Grünhagen DJ, et al. Multicenter Observational Study of Adhesion Formation after Open-and Laparoscopic Surgery for Colorectal Cancer. Ann Surg. 2018; 267(4):743-8.

5. Galli SJ, Kalesnikoff J, Grimbaldeston MA, Piliponsky AM, Williams CMM, Tsai M. Mast Cells As "Tunable" Effector And Immunoregulatory Cells: Recent Advances. Annu Rev Immunol. 2005;23(1):749-86.

6. Pejler G, Rönnberg E, Waern I, Wernersson S. Mast cell proteases: Multifaceted regulators of inflammatory disease. Blood. 2010;115(24): 4981-90.

7. Glantzounis GK, Tselepis AD, Tambaki AP, et al. Laparoscopic surgeryinduced changes in oxidative stress markers in human plasma. Surg Endosc. 2001;15(11):1315-9.

8. Sammour T, Kahokehr A, Soop M, Hill AG. Peritoneal damage: the inflammatory response and clinical implications of the neuro-immunohumoral axis. World J Surg. 2010;34(4):704-20.

9. Molinas CR, Binda MM, Manavella GD, Koninckx PR. Adhesion formation after laparoscopic surgery: what do we know about the role of the peritoneal environment? Facts Views Vis ObGyn. 2010;2(3):149-60.

10. Jacob HJ, Kwitek AE. Multifactorial genetics: Rat genetics: attachign physiology and pharmacology to the genome. Nat Rev Genet. 2002;3(1):33.

11. Sengupta P. A scientific review of age determination for a laboratory rat: how old is it in comparison with human age. Biomed Int. 2011;2(2):81-9.

12. Federer WT. Randomization and Sample Size in Experimentation. Randomization Sample Size Exp. 1966.

13. van den Bos R, Jolles J, van der Knaap L, Baars A, de Visser L. Male and female Wistar rats differ in decision-making performance in a rodent version of the lowa Gambling Task. Behav Brain Res. 2012;234(2):375-9.

14. Pritchett-Corning KR, Chang FT, Festing MFW. Breeding and Housing Laboratory Rats and Mice in the Same Room Does Not Affect the Growth or Reproduction of Either Species. J Am Assoc Lab Anim Sci. 2009;48(5): 492-8.

15. Suhartono E. Iskandar, Hamidah S, Arifin YF. Phytochemical constituents analysis and neuroprotective effect of leaves of gemor (Nothaphoebe coriacea) on cadmium-induced neurotoxicity in rats: An in-vitro study. Int J Toxicol Pharmacol Res. 2016;8(1):1-6.

16. Aebi H. Catalase in Vitro Methods Enzymol, vol. 105; 1984. p. 121-6.

17. Misra HP, Fridovich I. The role of superoxide anion in the autoxidation of epinephrine and a simple assay for superoxide dismutase. J Biol Chem. 1972;247(10):3170-5. 
18. Buege JA, Aust SD. Microsomal Lipid Peroxidation. Methods Enzymol. 1978; 52:302-10.

19. Hartoyo E, Thalib I, Maharani C, Sari P, Budianto WY, Suhartono E. A Different Approach to Assess Oxidative Stress in Dengue Hemorrhagic Fever Patients Through the Calculation of Oxidative Stress Index. J Trop Life Sci. 2017:7(3):237-42.

20. Altınel Y, Taspinar E, Özgüç H, Öztürk E, Akyıldız EÜ, Bagdas D. The protective effect of ClinOleic against post-surgical adhesions. Ulus Travma Acil Cerr Derg. 2014;20(1):1-6.

21. Baysal Z, Togrul T, Aksoy N, Cengiz M, Çelik H, Boleken ME, et al. Evaluation of total oxidative and antioxidative status in pediatric patients undergoing laparoscopic surgery. J Pediatr Surg. 2009;44(7):1367-70.

22. Sasaki M, Joh T. Inflammation and Ischemia-Reperfusion Injury in Gastrointestinal Tract and Antioxidant, Protective Agents. J Clin Biochem Nutr. 2007:40(1):1-12.

23. Sammour T, Mittal A, Loveday BP, Kahokehr A, Phillips AR. Windsor JA, et al Systematic review of oxidative stress associated with pneumoperitoneum. Br J Surg. 2009;96(8):836-50.

24. Wei YH, Lee HC. Oxidative stress, mitochondrial DNA mutation, and impairment of antioxidant enzymes in aging. Exp Biol Med. 2002;227(9):671-82.

25. van Langendonckt A, Casanas-Roux F, Donnez J. Oxidative stress and peritoneal endometriosis. Fertil Steril. 2002;77(5):861-70.

26. Víctor VM, de la Fuente M. Changes in the superoxide production and other macrophage functions could be related to the mortality of mice with endotoxin-induced oxidative stress. Physiol Res. 2003;52(1):101-10.

27. Oksuz H, Bulbuloglu E, Senoglu N, Ciralik H, Yuzbasioglu MF, Kilinc M, et al. Re-protective effects of pre- and post-laparoscopy conditioning, zinc, pentoxifylline, and $\mathrm{N}$-acetylcysteine in an animal model of laparoscopy-induced ischemia/reperfusion injury of the kidney. Ren Fail. 2009;31(4):297-302.

28. Horny H-P, Sotlar K, Valent P, Hartmann K. Mastocytosis: a disease of the hematopoietic stem cell. Dtsch Arztebl Int. 2008;105(40):686-92.

29. Orfao A, Garcia-Montero AC, Sanchez L, Escribano L. Recent advances in the understanding of mastocytosis: The role of KIT mutations. Br J Haematol. 2007;138(1):12-30.

30. Valent $P$, Akin C, Escribano L, Födinger M, Hartmann K, Brockow K, et al. Standards and standardization in mastocytosis: Consensus statements on diagnostics, treatment recommendations and response criteria. Eur J Clin Investig. 2007;37(6):435-53.

31. Krystel-Whittemore M, Dileepan KN, Wood JG. Mast cell: A multi-functional master cell. Front Immunol. 2016;6:1-12.

32. Dawicki W, Marshall JS. New and emerging roles for mast cells in host defence. Curr Opin Immunol. 2007;19(1):31-8.

33. Knight PA, Wright SH, Lawrence CE, Paterson YYW, Miller HRP. Delayed Expulsion of the Nematode Trichinella spiralis In Mice Lacking the Mucosa Mast Cell-Specific Granule Chymase, Mouse Mast Cell Protease-1. J Exp Med. 2000;192(12):1849-56.

34. Dahlin JS, Hallgren J. Mast cell progenitors: Origin, development and migration to tissues. Mol Immunol. 2015;63(1):9-17.

35. Sonoda T, Kanayama Y, Hara H, Hayashi C, Tadokoro M, Yonezawa T, et al. Proliferation of Peritoneal Mast Cells in the Skin of W/W Mice that Genetically Lack Mast Cells. J Exp Med. 1984;160:138-51.

36. Berlanga O, Emambokus N, Frampton J. GPIIb (CD41) integrin is expressed on mast cells and influences their adhesion properties. Exp Hematol. 2005; 33(4):403-12.

37. Rosenkranz AR, Coxon A, Maurer M. Impaired mast cell development and innate immunity in Mac-1 (CD11b/CD18, CR3)-deficient mice. J Immunol. 1998;161(12):6463-7.

38. Abonia JP, Hallgren J, Jones T, Shi T, Xu Y, Koni P, et al. Alpha-4 integrins and VCAM-1, but not MAdCAM-1, are essential for recruitment of mast cell progenitors to the inflamed lung. Blood. 2017;108:1588-95.

39. Jamur MC, Moreno AN, Mello LF, Júnior DA, Campos MR, Pastor MV, et al. Mast cell repopulation of the peritoneal cavity: contribution of mast cell progenitors versus bone marrow derived committed mast cell precursors. BMC Immunol. 2010;11(32):1-11.

40. Jones TG, Hallgren J, Humbles A, Burwell T, Finkelman FD, Alcaide $P$, et al Antigen-induced increases in pulmonary mast cell progenitor numbers depend on IL-9 and CD1d-restricted NKT cells. J Immunol. 2009;183(8):5251.

41. Volz J, Köster S, Weis M, Schmidt R, Urbaschek R, Melchert F, et al. Pathophysiologic features of a pneumoperitoneum at laparoscopy: A swine model. Am J Obstet Gynecol. 1996;174(1):132-40.
42. Chelombitko MA, Fedorov AV, Ilyinskaya OP, Zinovkin RA, Chernyak BV. Role of reactive oxygen species in mast cell degranulation. Biochem. 2016;81(12): 1564-77.

43. Steiner DR, Gonzalez NC, Wood JG. Mast cells mediate the microvascular inflammatory response to systemic hypoxia. J Appl Physiol. 2003;94:325-34.

44. Suzuki Y, Yoshimaru T, Inoue T, Niide O, Ra C. Role of oxidants in mast cell activation. Chem Immunol Allergy. 2005;87:32-42.

45. Yang W, Chen J, Zhou L. Effects of shear stress on intracellular calcium change and histamine release in rat basophilic leukemia (RBL-2H3) cells. J Environ Pathol Toxicol Oncol. 2009;28(3):223-30.

46. Zhang D, Spielmann AN, Wang LI, Ding GU, Huang FA, Gu QU, et al. Mastcell degranulation induced by physical stimuli involves the activation of transient-receptor-potential channel TRPV2. Physiol Res. 2012;61:113-24.

47. Hong-Tao M, Beaven MA. Regulators Of Ca2+ Signaling In Mast Cells Potential Targets for Treatment of Mast-Cell Related Diseases? Madame Curie. 2000:1-14.

48. van Golen RF, Reiniers MJ, Vrisekoop N, Zuurbier CJ, Olthof PB, van Rheenen J, et al. The Mechanisms and Physiological Relevance of Glycocalyx Degradation in Hepatic Ischemia/Reperfusion Injury. Antioxid Redox Signal. 2014;21(7):1098-118.

49. Alderton WK, Cooper CE, Knowles RG. Nitric Oxide Synthases: Structure, Function and Inhibition. Biochem. 2001;615:593-615.

50. Rubio-Gayosso I. Reactive oxygen species mediate modification of glycocalyx during ischemia-reperfusion injury. AJP Hear Circ Physiol. 2006; 290(6):2247-56.

51. Debray-García Y, Sánchez El, Rodríguez-Muñoz R, Venegas MA, Velazquez J, Reyes $J$ L. Diabetes and exposure to peritoneal dialysis solutions alter tight junction proteins and glucose transporters of rat peritoneal mesothelial cells. Life Sci. 2016;161:78-89.

52. Gotloib L, Wajsbrot V, Cuperman Y, Shostak A. Acute oxidative stress induces peritoneal hyperpermeability, mesothelial loss, and fibrosis. J Lab Clin Med. 2004;143(1):31-40.

53. Lee HB, Yu MR, Song JS, Ha H. Reactive oxygen species amplify protein kinase $C$ signaling in high glucose-induced fibronectin expression by human peritoneal mesothelial cells. Kidney Int. 2004;65(4):1170-9.

54. Tchougounova E, Forsberg E, Angelborg G, Kjellén L, Pejler G. Altered processing of fibronectin in mice lacking heparin. A role for heparindependent mast cell chymase in fibronectin degradation. J Biol Chem. 2001 276(6):3772-7.

55. Scudamore $\mathrm{CL}$, Jepson MA, Hirst BH, Miller HRP. The rat mucosal mast cell chymase, RMCP-II, alters epithelial cell monolayer permeability in association with altered distribution of the tight junction proteins ZO-1 and occludin. Eur J Cell Biol. 1998;75:321-30.

56. Annecke T, Fischer J, Hartmann H, Tschoep J, Rehm M, Conzen P, et al. Shedding of the coronary endothelial glycocalyx: effects of hypoxia/ reoxygenation vs ischaemia/reperfusion. Br J Anaesth. 2011;107(5):679-86.

57. Yung S, Chan TM. Mesothelial cells. Perit Dial Int. 2007;27(2):110-5.

58. Yung S, Chan TM. Pathophysiological changes to the peritoneal membrane during PD-related peritonitis: the role of mesothelial cells. Mediat Inflamm. 2012:1-21.

\section{Publisher's Note}

Springer Nature remains neutral with regard to jurisdictional claims in published maps and institutional affiliations.

Ready to submit your research? Choose BMC and benefit from:

- fast, convenient online submission

- thorough peer review by experienced researchers in your field

- rapid publication on acceptance

- support for research data, including large and complex data types

- gold Open Access which fosters wider collaboration and increased citations

- maximum visibility for your research: over $100 \mathrm{M}$ website views per year

At $\mathrm{BMC}$, research is always in progress.

Learn more biomedcentral.com/submissions 